\title{
Evidence for the duplication of PGI genes in Dipcadi serotinum L. (Liliaceae)
}

\author{
L. Pascual, \\ I. A. Márquez and \\ D. López-Alonso*
}

\author{
Departmento de Biologia Animal, \\ Ecología y Genética \\ Facultad de Ciencias, \\ 18071 Granada, Spain. \\ * Departamento de Biología Animal, \\ Ecología y Genética, \\ Colegio Universitario de Almería, \\ 04071 Almería, Spain.
}

Analysis of electrophoretic phenotypes for phosphoglucoisomerase isozymes (PGI, EC 5.3.1.9) in Spanish populations of Dipcadi serotinum L. shows that this diploid species has three gene loci coding for PGI isozymes. The PGI-1 locus specifying the plastid isozymes has two alleles and is probably duplicated since the three banded phenotypes represents a fixed heterozygote which does not segregate among progenies. PGI-2 and PGI-3 loci specifying the cytoplasmic isozymes have three and five alleles respectively and they produce complex non-overlapping phenotypes with the formation of interlocus heterodimers between polypeptides specified by the PGI-2 and PGI-3 loci. These results suggest that the two loci coding for the cytosolic isozymes have arisen by the duplication of an ancestral gene.

\section{INTRODUCTION}

The use of electrophoresis in diploid plants to identify the number of gene loci that specify particular enzyme systems has revealed that, in most higher plants, the minimum number and subcellular location of isozymes of many assayed enzymes are highly conserved (Gottlieb, 1982). Nevertheless gene duplication in diploid plants has played an important role in increasing this minimum isozyme number. Gene duplication has been extensively reported in several species of diploid plants, for example, for genes coding for phosphoglucoisomerase (PGI) in Clarkia (Gottlieb, 1977; Gottlieb and Weeden, 1979) and for other enzyme systems, in Stephanomeria (Roose and Gottlieb, 1980), Clarkia (Gottlieb, 1974; Pichersky and Gottlieb, 1983; Soltis et al., 1987), Heliantus (Torres, 1974), Sorghum (Ellstrand et al., 1983), Hordeum (Kahler et al., 1981) and Layia (Warwick and Gottlieb, 1985).

In this paper we present evidence of PGI duplication in the diploid species Dipcadi serotinum L. Medic. With $2 n=8$ chromosomes (Ruiz Rejón et al., 1980). This species is the only representative of the Genus Dipcadi present in Spain (Heywood in Tutin et al., 1980). In a previous report (Oliver et al., 1983) the four zones of PGI activity present in this species were considered as products of four different genes, and due to the complexity of the zymograms by the appearance of additional anodal bands originated by postranslational modifications, some of the PGI isozymes seemed to be coded by duplicated genes. The modification of our electrophoresis techniques simplifies the zymograms leading to match our results with the PGI patterns present in other diploid species.

\section{MATERIAL AND METHODS}

Plants of Dipcadi serotinum L. $(2 n=8)$ were collected from seven Spanish natural populations: locations and sample size of each population are listed in table 1 .

Identification of the subcellular locations and number of gene loci which specify PGI isozymes was initially conducted by a comparative examination of extracts of diploid somatic tissues (leaves), and soaked pollen of individual plants (following Weeden and Gottlieb, 1979, 1980b). A formal genetic analysis was then conducted on seeds derived from single outcrossed plants sampled from natural populations and also on the progenies derived from experimental self-pollination of different individuals.

Enzyme extracts were absorbed onto paper wicks and subjected to horizontal starch gel electrophoresis, with $\mathrm{LiOH} /$ borate $p \mathrm{H} \quad 8 \cdot 1$ electrode buffer and Tris/citrate $p \mathrm{H} 8 \cdot 3$ gel buffer 
Table 1 Populations of $D$. serotinum examined for PGI

\begin{tabular}{ll}
\hline Location & Sample size \\
\hline Sitio de Calahonda, Marbella, Malaga & 24 \\
Cerro Gorde, Almuñecar, Granada & 52 \\
Calahonda, Granada & 52 \\
Viator, Almería & 39 \\
Balcón de Canales, S. Nevada, Granada & 71 \\
Cerro del Toro, S. Nevada, Granada & 36 \\
Padul, Granda & 25 \\
\hline
\end{tabular}

(Selander et al., 1971). EDTA $5 \mathrm{mM}$ was added to the gel and electrode buffers in order to inhibit calcium dependent proteases. The addition of EDTA together with the use of extracts for electrophoresis prepared in suitable buffers (Weeden and Gottlieb, 1979, 1980 b) simplifies the zymograms, eliminating additional bands that are resolved under other technical conditions as crude extracts obtained by crushing the plant material in deionised water (Oliver et al., 1983). Gels were stained for PGI activity as described by Wendel (1980).

\section{RESULTS AND DICUSSION}

Analysis of different electrophoretic phenotypes of PGI from leaves of Dipcadi serotinum reveals that there exist four clearly separated zones of PGI activity (fig. 1). They are in decreasing order of anodal mobility, PGI-1, PGI-2, PGI-2/3 and PGI-3. The PGI-2/3 bands represent interlocus hybrid enzymes formed between the subunits coded by the genes PGI-2 and PGI-3 (explanation given below).

A comparison of zymograms of leaf and soaked pollen extracts shows that they are distinguished

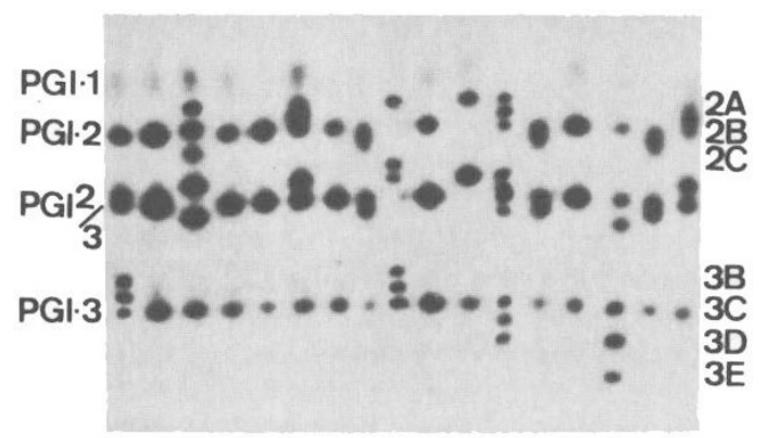

Figure 1 Electrophoretic phenotypes of PGI enzymes from some individuals of $D$. serotinum. The four PGI zones are indicated at the left and the homodimeric enzymes of cytoplasmic isozymes at the right, the homodimeric enzyme $3 \mathrm{~A}$ is absent in these individuals and is not shown. by the absence from leachate pollen of the isozymes of the PGI-1 zone (fig. 2). This suggests that the PGI-1 isozymes are located in the plastids as also noted in other plant species (Schnarrenberger and Oeser, 1974, Schnarrenberger et al., 1975; Weeden and Gottlieb, 1979, 1980a, 1980b, Gottlieb and Weeden, 1981; Gottlieb, 1982; Lack and Kay, 1986). The PGI-1 zone is weakly stained in relation to the other zones and was not well resolved in the majority of individuals analysed; for this reason data from only 40 individuals are available. In this initial survey only two different phenotypes were found in the PGI-1 zone; 36 individuals had a single banded pattern designated $1 \mathrm{~A}$ (the most anodal band)-these are considered to be homozygous for PGI-1A; the remaining four individuals show three electrophoretic bands (fig. 3), having the same $1 \mathrm{~A}$ band plus two less anodal isozymes designated $1 \mathrm{AB}$ and $1 \mathrm{~B}$ - this is the typical pattern for a heterozygous state of a dimeric enzyme. As all the seeds produced by these heterozygous plants were also three banded in the PGI-1 zone, it would seem that in these four plants the PGI locus is duplicated and this has given rise to a state of fixed heterozygosity at the PGI-1 locus (Allendorf et al., 1975; Gottlieb, 1976; Oliver et al., 1983). The single banded pattern exhibited by the majority of individuals, therefore, may be due to each duplicated gene of PGI-1 possessing identical alleles or alternatively one of the duplicated genes codes for a null allele. Additional data (e.g. studies of dosage effects, etc.) are required before a firmer conclusion is reached on this point.

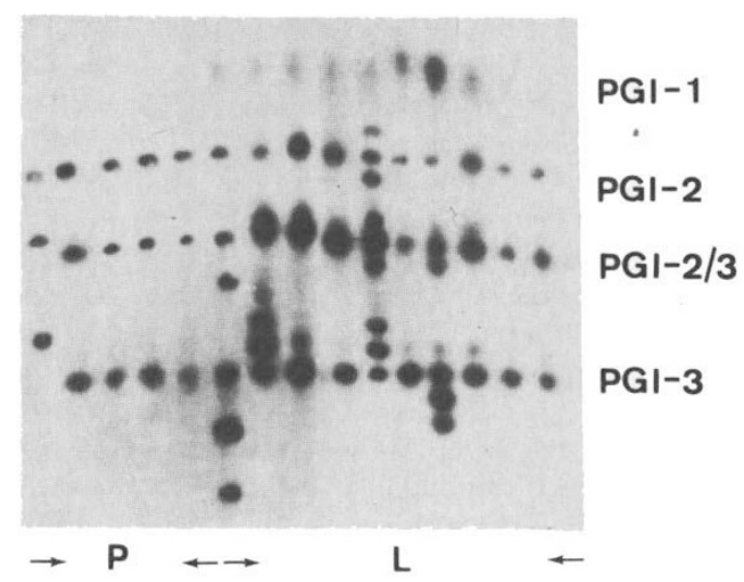

Figure 2 Comparative analysis of soaked pollen and leaf extracts that shows the absence of PGI-1 or plastid PGI isozymes and the presence of intergenic heterodimers (PGI-2/3) between the cytosolic isozymes PGI-2 and PGI-3. 


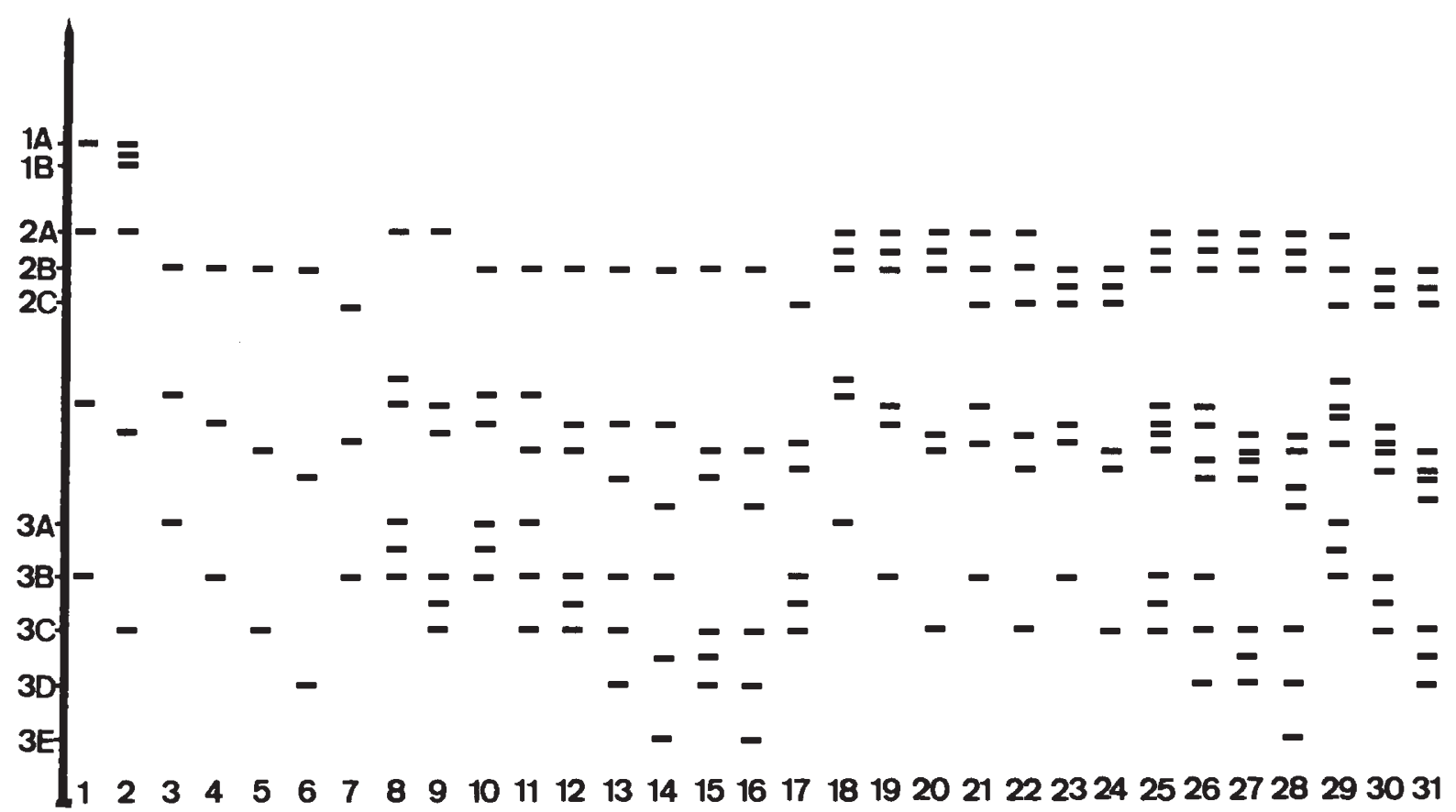

Figure 3 Diagrammatic representation of PGI phenotypes observed in $D$. serotinum. Each phenotype is designated by a number. The homodimeric enzymes are indicated at the left. Intensity of heterodimeric enzyme bands is not indicated in the figure. Only the two found phenotypes for PGI-1 are represented.

The remaining zones of activity PGI-2, PGI-2/3 and PGI-3 were present in both soaked pollen and leaf extracts indicating that their isozymes have a cytosolic location (Weeden and Gottlieb, 1980b). For dimeric isozymes postmeiotically expressed in pollen (e.g., the cytosolic PGI isozymes) a comparison between the electrophoretic patterns expressed in pollen and somatic tissues can provide valuable information on the number of gene loci present and their allelic states (Weeden and Gottlieb, 1979).

For the cytosolic isozymes of PGI in $D$. serotinum, individual plants show three to ten isozyme bands in somatic tissues (figs 1 and 3 ). The individuals with three banded phenotypes (fig. 3 ; individuals 1 to 7 ) show no differences between leaf extracts and soaked pollen isozymes (fig. 4), indicating that these dimeric phenotypes are specified by two gene loci (Gottlieb, 1977; Gottlieb and Weeden, 1979; Weeden and Gottlieb, 1979; Lack and Kay, 1986) that we have called PGI-2 and PGI-3.

The subunits coded by PGI-2 and PGI-3 associate to form interlocus hybrid enzymes PGI-2/3, with mobilities approximately intermediate to those of the respective intralocus homodimers; for

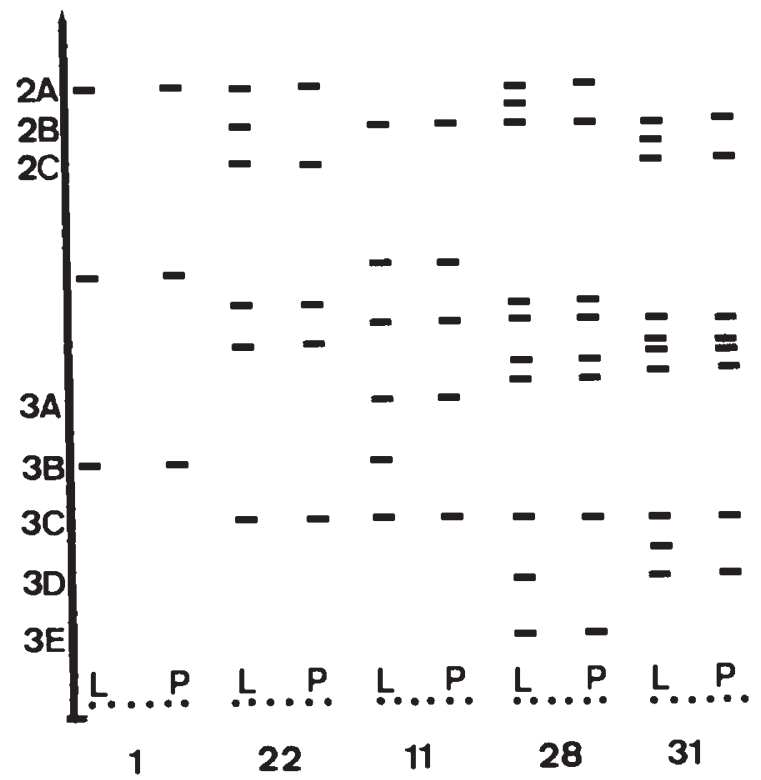

Figure 4 Diagrammatic representation of the comparative analysis of cytosolic PGI patterns in leaves (L) and soaked pollen $(P)$ of different individuals, where the absence of intragenic or allozyme heterodimers in the pollen from individuals heterozygous at either loci can be observed. 
this reason the heterodimeric isozymes that have originated by interlocus hybridisation are present in haploid pollen. In the PGI-2 zone three different bands occur; these are the products of the PGI-2 alleles which we have denoted as $2 \mathrm{~A}, 2 \mathrm{~B}$ and $2 \mathrm{C}$. In the PGI-3 zone four bands were initially found; these are the products of the PGI-3 alleles $3 \mathrm{~A}, 3 \mathrm{~B}$, $3 \mathrm{C}$ and $3 \mathrm{D}$. In this sense individuals 1-7 (fig. 3) are homozygous at both loci and the following phenotypes and genotypes (between parentheses) have been assigned to them: $2 \mathrm{~A} 3 \mathrm{~B}\left(2^{\mathrm{aa}} 3^{\mathrm{bb}}\right), 2 \mathrm{~A} 3 \mathrm{C}$ $\left(2^{\mathrm{aa}} 3^{\mathrm{cc}}\right), 2 \mathrm{~B} 3 \mathrm{~A}\left(2^{\mathrm{bb}} 3^{\mathrm{aa}}\right), 2 \mathrm{~B} 3 \mathrm{~B}\left(2^{\mathrm{bb}} 3^{\mathrm{bb}}\right), 2 \mathrm{~B} 3 \mathrm{C}$ $\left(2^{\mathrm{bb}} 3^{\mathrm{cc}}\right), 2 \mathrm{~B} 3 \mathrm{D}\left(2^{\mathrm{bb}} 3^{\mathrm{dd}}\right)$ and $2 \mathrm{C} 3 \mathrm{~B}\left(2^{\mathrm{cc}} 3^{\mathrm{bb}}\right)$. Other results can be explained using this model.

When individuals are heterozygous at just one of the two loci proposed, phenotypes with six bands always appear in diploid tissues (figs 1 and 3). So if the PGI-2 and PGI-3 loci are respectively homozygous and heterozygous (fig. 3 ; individuals 8 to 17) the phenotypes observed contain one band corresponding to the homodimer for the PGI-2 gene, two intermediate bands corresponding to interlocus heterodimers and three bands for the locus PGI-3 including two homodimers and one intermediate intralocus heterodimer typical of dimeric enzymes. If, however, the PGI-2 gene is heterozygous and the PGI-3 gene is homozygous, then there will appear phenotypes with three bands for PGI-2 zone, two bands for PGI-2/3 zone and one band for PGI-3 (fig. 3; individuals 18 to 24). Fig. 4 shows that pollen extracts from all of these individuals express not six but only five bands.

When both loci are heterozygous, ten isozymes may be observed in leaf extracts with the three fastest bands being dimer products of the PGI-2 alleles, the three slowest bands being dimer products of the PGI-3 alleles and the four intermediate bands being heterodimer products of interlocus hybridization (fig. 3; individuals 25 to 31 ). Pollen extracts of these individuals present not ten but only eight isozymes (fig. 4).

In both cases the observed reduction in the number of bands in soaked pollen extracts (fig. 4) is due to the fact that the intralocus or allozyme heterodimers are absent in haploid tissues since the pollen grains contain only one allele of each heterozygous locus. This fact allows us to determine the allelic state of the different loci and confirm the genotypes proposed.

The number and mobilities of the enzymes intermediate to PGI-2 and PGI-3 are perfectly correlated with the number and mobilities of the particular homodimeric PGI-2 and PGI-3 enzymes of each individual and they suggest, therefore, that these intermediate enzymes are interlocus heterodimers. The results of a genetic analysis of these two loci PGI-2 and PGI-3 based upon the segregation of progeny phenotypes were found to be consistent with the Mendelian inheritance of three and five co-dominant alleles, respectively (table 2). No information has been obtained on any linkage between the two cytosolic loci, since the seed progenies obtained from the double heterozygous individuals were scarce.

In conclusion, the electrophoretic results provide evidence that the plastid and the cytosolic isozymes of PGI in D. serotinum are coded by duplicated genes.

Several pieces of evidence reinforce this duplication model: since most diploid plants present only two isozymes for the PGI, one in the plastids and another in the cytoplasm, this reflects a remarkable conservation of metabolic activities in the different subcellular compartments and seems to indicate that two isozymes are the ancestral number for PGI in diploid plants (Gottlieb, 1982). Therefore the presence of additional isozymes of PGI in the same subcellular compartment is evidence of gene duplication for both plastid and cytosolic PGI isozymes. Furthermore, the formation of interlocus hybrids enzymes within each compartment, by the association of subunits coded by different gene loci, provides a strong evidence for their homology, and for the duplicated origin of the gene loci coding for these isozymes. Examples of such gene duplications have been documented in animals and plants (Ingran, 1961; Markert et al., 1975; Avise and Kitto, 1973;

Table 2 PGI phenotypes of progenies obtained from seeds collected from outcrossed plants in nature and from experimental self-pollination* of single individuals for the PGI-2 and PGI-3 genes. This analysis shows allelic segregation for both loci

\begin{tabular}{lll}
\hline $\begin{array}{l}\text { Parental } \\
\text { phenotypes }\end{array}$ & $\begin{array}{l}\text { Progeny } \\
\text { phenotypes }\end{array}$ & $\begin{array}{l}\text { Observed } \\
\text { frequencies }\end{array}$ \\
\hline 2A3B & 2B3B & 10 \\
& 2B3A & 1 \\
$2 B 3 A B$ & 2B3AB & 3 \\
& 2B3B & 6 \\
$2 \mathrm{C} 3 \mathrm{BD}$ & 2C3BC & 6 \\
& 2BC3CD & 6 \\
& 2A3B & 2 \\
2AC3B & 2AC3AB & 5 \\
& 2C3B & 1 \\
2B3C* & 2B3C & 10 \\
$2 \mathrm{~A} 3 \mathrm{~B}^{*}$ & 2A3B & 8 \\
& 2B3B & 6 \\
2BC3B* & 2BC3B & 10 \\
& 2C3B & 4 \\
\hline
\end{tabular}


Gottlieb, 1977; Pichersky and Gottlieb, 1983; Ellstrand et al., 1983; Warwick and Gottlieb, 1985).

The two loci coding for the cytosolic isozymes of PGI in D. serotinum have diverged structurally and must differ significantly in their sequences, because none of the electrophoretic variants at either locus overlap the mobility of any variant at the other. For the plastid PGI isozymes the lack of variability for these enzymes precludes a complete analysis.

On the other hand, the existence of additional isozymes in $D$. serotinum, in contrast to other closely related diploid species, belonging to the tribe Scilae Engler, as Muscari comosum and Scilla autumnalis, which just have two PGI isozymes (Pascual, unpublished data), permits one to think that gene duplications have occurred during the evolution of $D$. serotinum. This is the same as has happened during evolutive divergence of some diploid species of the genus Clarkia, which present two genes for cytosolic PGI (Gottlieb, 1977; Weeden and Gottlieb, 1979, 1980 b).

Regarding the possible origin of gene duplication for PGI isozymes in $D$. serotinum, cytological analysis shows an asymmetric karyotype with $n=4$ subteleocentric chromosomes, thus chromosome rearrangements in association with its capability for self-pollination, could have played an important role in the evolution of this species generating gene duplications (Ruiz Rejón et al., 1981). This suggestion is consistent with the existence of other duplicataed isozymes as alcohol dehydrogenase, glutamate-oxalacetate transaminase and esterases (Pascual et al., 1980, 1981; Pascual, 1983; Oliver et al., 1983.

\section{REFERENCES}

ALlENDORF, F. W., UTTER, F. M. AND MAY, B. P. 1975. Gene duplication within the family Salmonidae: II. Detection and determination of the genetic control of duplicate loci through inheritance studies and the examination of populations. Marker, C. L. (ed.). In Isozymes vol. 4: Genetics and evolution, Academic Press, New York, pp. 415-432.

AVISE, J. C. AND KITTO, B. G. 1973. Phosphoglucose isomerase gene duplication in the bony fishes: an evolutionary history. Biochem. Genet., 8, 113-132.

ELLSTRAND, N. C., LEE, J. M. AND FOSTER, K. W. 1983. Alcohol dehydrogenase isozymes in grain sorghum (Sorghum bicolor): evidence for a gene duplication. Biochem. Genet, $21,147-154$.

GOTTLIEB, L. D. 1974. Gene duplication and fixed heterozygosity for alcohol dehydrogenase in the diploid plant Clarkia franciscana. Proc. Nat. Acad. Sci. USA. 71, 18161818.

GOTTLIEB, L. D. 1976. Biochemical consequences of speciation in plants. Ayala, F. J. (ed.) Molecular Evolution Sinauer Associataes, Sunderland. Massachusetts.
GOTTLiEB, L. D. 1977. Evidence for duplication and divergence of the structural gene for phosphoglucoisomerase in diploid species of Clarkia. Genetics, 86, 289-307.

GOTTLIEB, L. D. 1982. Conservation and duplication of isozymes in plants. Science, 216, 373-380.

GOTTLIEB, L. D. AND WEEDEN, N. F. 1979. Gene duplication and phylogeny in Clarkia. Evolution, 33, 1024-1039.

GOTTLIEB, L. D. AND WEEDEN, N. F. 1981. Correlation between subcellular location and phosphoglucose isomerase variability. Evolution, 35, 1019-1022.

INGRAN, V. M. 1961. Gene evolution and the haemoglobins. Nature, 189, 704-708.

KAHLER, A. L., MORRIS, M. I. AND ALLARD, R. W. 1981. Gene triplication and fixed heterozygosity in diploid wild barley. J. Heredity, 72, 374-376.

LACK, A. J. AND KAY, Q. O. N. 1986. Phosphoglucose isomerase (EC 5.3.1.9) isozymes in diploid and tetraploid Polygala species: evidence for gene duplication and diversification. Heredity, 56, 111-118.

MARKERT, C. L., SHAKLEE, J. B. AND WHITT, G. S. 1975. Evolution of a gene. Science, 189, 102-114.

OLIVER, J. L., MARTINEZ ZAPATER, J. M., PASCUAL, L., ENRIQUEZ, A. M., RUIZ REJON, C. AND RUIZ REJON, M. 1983. Different genome amplification mechanisms and duplicate gene expression in Liliaceae. In "Isozymes: Current Topics in Biological and Medical Research vol. 10: Genetics and Evolution" Alan R. Liss Inc., New York, pp. 341-363.

PASCUAL, L., 1983. Variabilidad isoenzimática en poblaciones naturales de especies españolas del orden Liliales: dupliciones génicas especiaión. Tesis Doctoral. Fac. de Ciencias, Univ. de Granada. Spain.

PASCUAL, L., RUIZ REJON, M., OLIVER, J. L. AND RUIZ REJON, C. 1980 . Existence of ADH gene duplication in the diploid level of Dipcadi serotinum (L.) Medic. Isozyme Bull., 13, 63.

PASCUAL, L., RUIZ REJON, M., OLIVER, J. L. AND RUIZ REJON, C. 1981. Existence of gene duplication in ADH-2 of Dipcadi serotinum. Isozyme Bull., 14, 56.

PICHERSKY, E. AND GOTTLIEB, L. D. 1983. Evidence for duplication of the structural genes coding plastid and cytosolic isozymes of triose phosphate isomerase in diploid species of Clarkia. Genetics, 105, 421-436.

Roose, M. L. AND GOTTLIEB, L. D. 1980. Alcohol dehydrogenase in the diploid plant Stephanomeria exigua (Compositae). Gene duplication, mode of inheritance and linkage. Genetics, 95, 171-187.

RUIZ REJON, M., OLIVER, J. L., RUIZ REJON, C, PASCUAL, L., SOTO, J. AND TEJERO, E. 1980. Números cromosómicos para la flora española. Números 121-126. Lagascalia, 9, 249-254.

RUIZ REJON, M., RUIZ REJON, C. AND PASCUAL, . 1981. The chromosome system of Dipcadi serotinum (Liliaceae): a natural species with unusual cytogenetic characteristicis. Caryologia, 34, 419-429.

SCHNARRENBERGER, C. M. AND OESER, A. 1974. Two isozymes of glucose-6-phosphate isomerase from spinach leaves and their intracellular compartmentation. Eur. J. Biochem., 45, 77-82.

SCHNARRENBERGER, C. M., TETOUR, M. AND HERBERT, M. 1975. Development and intracellular distribution of enzymes of the oxidative pentose phosphate cycle in radish cotyledons. Plant Physiol., 56, 836-840.

SELANDER, R. K., SMITH, M. H., YANG, S. Y., JOHNSON, W. E. AND GENTRY, J. B. 1971. Biochemical polymorphism and systematics in the genus Peromyscus. I. Variation in the old-field mouse (Peromyscus polionotus). Univ. of Texas Publications, 7103, 49-90. 
SOLTIS, P. S., SOlTIS, D. E. AND GOTTLIEB, L. D. 1987. Phosphoglucomutase gene duplications in Clarkia (Onagraceae) and their phylogenetic implications. Evolution, 41, 667-671.

TORRES, A. M., 1974. An intergenic alcohol dehydrogenase isozyme in sunflowers. Biochem. Genet., 11, 301-308.

TUTIN, T. G., HEYWOOD, V. H., BURGES, N. A., MOORE, D. M., VALENTINE, D. H., WALTERS, S. M. AND WEBB, D. A. 1980. Flora Europea, Cambridge Univ. Press.

WARWICK, S. I. AND GOTTLIEB, L. D. 1985. Genetic divergence and geographic speciation in Layia (Compositae). Evol ution, 39, 1236-1241.
WEEDEN, N. F. AND GOTTLIEB, L. D. 1979. Distinguishing allozymes and isozymes of phosphoglucoisomerase by electrophoretic comparisons of pollen and somatic tissues. Biochem. Genet., 17, 287-296.

WEEDEN, N. F. AND GOTTLIEB, L. D. 1980a. The genetics of chloroplast enzymes. J. Heredity, 71, 392-396.

WEEDEN, N. F. AND GOTTLIEB, L. D. $1980 \mathrm{~b}$. Isolation of cytoplasmic enzymes from pollen. Plant Physiol., 66, 400-403.

WENDEL, J. F., 1980. Enzyme extraction from a tannin rich plant. Isozyme Bull., 13, 116. 